\title{
Impacts of Climate Change on the Hydrology of a Small Brazilian Headwater Catchment Using the Distributed Hydrology-Soil-Vegetation Model
}

\author{
Lívia Alves Alvarenga ${ }^{1}$, Carlos Rogério de Mello ${ }^{1}$, Alberto Colombo', Sin Chan $\mathrm{Chou}^{2}$, \\ Luz Adriana Cuartas ${ }^{3}$, Marcelo Ribeiro Viola ${ }^{1}$ \\ ${ }^{1}$ Department of Engineering, Federal University of Lavras, Lavras, Brazil \\ ${ }^{2}$ National Institute for Space Research, Cachoeira Paulista, Brazil \\ ${ }^{3}$ Center for Monitoring and Warning of Natural Disasters, São José dos Campos, Brazil \\ Email: livia.aalvarenga@deg.ufla.br
}

How to cite this paper: Alvarenga, L.A, de Mello, C.R., Colombo, A., Chou, S.C., Cuartas, L.A. and Viola, M.R. (2018) Impacts of Climate Change on the Hydrology of a Small Brazilian Headwater Catchment Using the Distributed Hydrology-SoilVegetation Model. American Journal of Climate Change, 7, 355-366.

https://doi.org/10.4236/ajcc.2018.72021

Received: March 21, 2018

Accepted: June 26, 2018

Published: June 29, 2018

Copyright () 2018 by authors and Scientific Research Publishing Inc. This work is licensed under the Creative Commons Attribution International License (CC BY 4.0).

http://creativecommons.org/licenses/by/4.0/

\section{(c) (i) Open Access}

\begin{abstract}
Climate change is one of the greatest issues for human society. The objective of this study is to assess the impacts of future climate change on seasonal average discharge and monthly water budget in a small headwater catchment, located on the Grande River basin, in Minas Gerais, Brazil. The assessment is carried out using the hydrology model, DHSVM. The atmospheric forcing to drive the Distributed Hydrology-Soil-Vegetation Model (DHSVM) is derived from the downscaling of the HadGEM2-ES projections by the Eta Regional Climate Model, at 5-km high resolution. The projections assume the RCP4.5 and RCP8.5 IPCC AR5 emission scenarios. Baseline period was taken between 1961 and 1990. The projections are assessed in three time slices (2011-2040, 2041-2070 and 2071-2099). The climate change is assessed in time slices of 30 years and in comparison against the baseline period to evaluate the hydrological changes in the catchment. The results showed differences in the hydrological behavior between the emission scenarios and though time slices. Reductions in the magnitude of the seasonal average discharge and monthly water budget may alter the water availability. Under the RCP4.5 scenario, results show greater reductions in the water availability in the first time slice, whereas under RCP8.5 scenario greater reductions are indicated in the third time slice.
\end{abstract}

\section{Keywords}

Climate Changes, RCP4.5 and RCP8.5 Scenarios, Hydrological Model, Discharge 


\section{Introduction}

The Southeast region of Brazil is extremely relevant for the social and economic development of the country. The Grande River basin is located in southeastern Brazil and the Tropical Atlantic Forest in its headwater region (Mantiqueira Range), should be highlighted as one of the most important biodiversity hotspot of the world [1] [2]. In this basin, the annual variability of precipitation and temperature can be critical for human water consumption, irrigation, and hydropower generation [3] [4].

Southeastern Brazil, in the hydrological years of 2013/2014 and 2014/2015, experienced the worst water crisis yet observed due to rainfall much below average and high temperatures in the summer [5] [6] [7]. That water crisis may be associated with a number of factors, such as: socio-spatial disparities, losses in the water distribution networks, poor infrastructure, inadequate political actions for socioeconomic development and environmental education, and deforestation of the Atlantic Forest [7] [8] [9] [10].

The spatial-temporal patterns that characterize the hydrological response of a catchment can be altered due to climate changes. These changes may vary in intensity according to climatic characteristics, land surface saturation and with the magnitude of the change [11]. Climatic changes may impact the water balance in several ways, such as changes in the evapotranspiration, soil moisture content, groundwater storage and discharge regime [12] [13] [14] [15].

[11] evaluated precipitation, evapotranspiration, discharge, and soil moisture changes on the Brazilian major National Hydrographic basins using downscaling projections of HadGEM2-ES and MIROC5 under two RCP scenarios, and the MGB-IPH hydrological model. The assessment of the water availability shows projected reduction in almost the entire country, except in the south of Brazil. The results suggest that the projected changes may trigger the occurrence of natural disasters such as droughts and flash floods, which could increase vulnerability of people living in risk areas.

Some studies on climate changes and their effects on the Grande River basin have indicated that both temperature and precipitation would affect discharge and surface runoff in different hydrographic basin scale [12] [16] [17]. As reported recently by [12], projected discharges throughout the 21 st century in the Lavrinha catchment, located in Mantiqueira Range region show drastic changes. These authors used the Distributed Hydrology-Soil-Vegetation Model (DHSVM) driven by the downscaling projections of the Eta/HadGEM2-ES under RCP8.5 scenario. Moreover, the use of a physically based fully distributed hydrologic model, e.g. DHSVM, is essential for quantitatively evaluating climate change impacts on hydrology of headwater catchments. The projected changes resulted in a monthly and annual average reduction of the discharge of up to $77 \%$ and $69 \%$, respectively.

The changes in the context of different scenarios are valuable for assisting management of water resources. The objective of this research is to investigate the possible changes on seasonal average discharge and monthly water budget 
using the DHSVM. The novelty of this research is the evaluation of the hydrological impacts projected by two RCP4.5 and RCP8.5 scenarios using the downscaling of the HadGEM2-ES by the Eta Regional Climate Model at high resolution, in a $6.76 \mathrm{~km}^{2}$ catchment's drainage area, located in the Grande River basin headwater region. Furthermore, this is the second survey using DHSVM to analyze possible hydrological impacts under AR5 emission scenarios in Brazil.

\section{Material and Methods}

\subsection{Site Description}

This study was carried out in Lavrinha Creek Catchment (LCC), a headwater basin located in the Mantiqueira Range region, in Southeastern Brazil (Figure 1). LCC, shelters the last remnants of the ecologically important Upper Montane Tropical Forest. In addition, the Atlantic forest in these areas is an important biome in danger of extinction [1]. The choice for studying this basin is the vulnerability due to the possible climate changes in the basin scale. Table 1 shows the characteristics of the LCC.

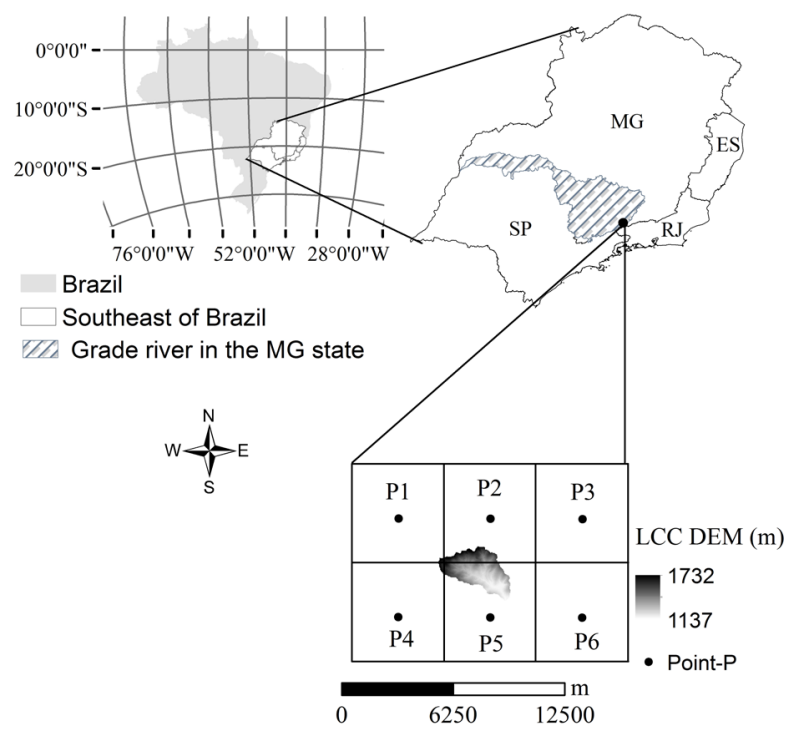

Figure 1. Location, topography and Eta model grid boxes around LCC catchment.

Table 1. Characteristics of the LCC.

\begin{tabular}{cc}
\hline Area & $6.76 \mathrm{~km}^{2}$ \\
\hline Elevation & 1137 to $1733 \mathrm{~m}$ \\
Climate & Cwb (according to Koppen classification method) \\
Average annual temperature & $17^{\circ} \mathrm{C}$ \\
Average annual rainfall & $2045 \mathrm{~mm}$ \\
Vegetation types & Atlantic Forest and Grassland \\
Soil types & Haplic Cambisol, Fluvic Neosol and Haplic Gleisol \\
\hline
\end{tabular}




\subsection{DHSVM and Spatial and Hydrometeorological Data}

The Distributed Hydrology Soil Vegetation Model (DHSVM) is a physically based, spatially distributed hydrology model, developed by [18]. In this model, the spatial distribution of soil moisture with multilayer unsaturated soil and a saturated subsurface, evaporation with two-layer canopy representation for interception and evaporation; runoff production with generation through saturation excess and infiltration excess mechanisms; within the stream, the linear reservoir routing method is used for each river segment; and simulated at hourly time steps. This model subdivides a catchment into uniform cells $(30 \mathrm{~m}$ in this study) to capture the spatial variability of the physical characteristics of the catchment at the spatial resolution of a DEM-Digital Elevation Model (Figure 1). To run the model, input soil and vegetation parameters are required for each pixel. Digital elevation data are used in the model for flow routing, estimation of soil depth distribution, and meteorological data extrapolation. The meteorological station is located in the coordinates of $22^{\circ} 07^{\prime} \mathrm{S}$ and $44^{\circ} 27^{\prime} \mathrm{W}$ within the LCC (in the average elevation). Meteorological inputs required by DHSVM includes: precipitation $(\mathrm{m})$, temperature $\left({ }^{\circ} \mathrm{C}\right)$, wind speed $\left(\mathrm{m} \mathrm{s}^{-1}\right)$, relative humidity $(\%)$, and shortwave and longwave solar radiation $\left(\mathrm{W} \mathrm{m}^{-2}\right)$ (hourly in this study). Long wave radiation was calculated as described by [19].

DEM for the catchment was obtained from a 1:50,000 contour map at a spatial resolution of $30 \mathrm{~m}$ (Instituto Brasileiro de Geografia e Estatística-IBGE, 1973). The DEM was used to define the LCC. The stream network was generated using the flow routing module based on DEM. Soil depth data were calculated according to the water table depth observations in the LCC [20], being estimated, respectively, the minimum and maximum values, as 2.5 and $5.0 \mathrm{~m}$. Parameters used to represent the vegetation and soil for the DHSVM simulations are listed in [3]. The soil type data in 30-m spatial resolution was obtained from [21]. Two vegetation classes, grassland and Atlantic Forest, were derived from an ALOS (Advanced Land Observing Satellite) image from 2008, using a maximum likelihood supervised classification with ground-based validation points (Figure 2).

\subsection{DHSVM Simulations}

LCC was monitored and studied from 2005 to 2010, within the scope of a wider research and development project sponsored by CEMIG to study the hydrology of the Upper Grande River basin. From information obtained in the field surveys and laboratory analysis, it was possible to obtain the data required to use the Distributed Hydrology Soil Vegetation Model (DHSVM) on a GIS platform. The meteorological record from January 2005 to December 2010 has been run through the DHSVM (hourly). One year and 9 months period was chosen for warm up DHSVM continuous simulations, aiming to reduce uncertainties about initial soil moisture condition to reach equilibrium. Monthly discharge output from the DHSVM simulations were compared against the observed data for the same period. The hydrological year in the region encompasses October of one 


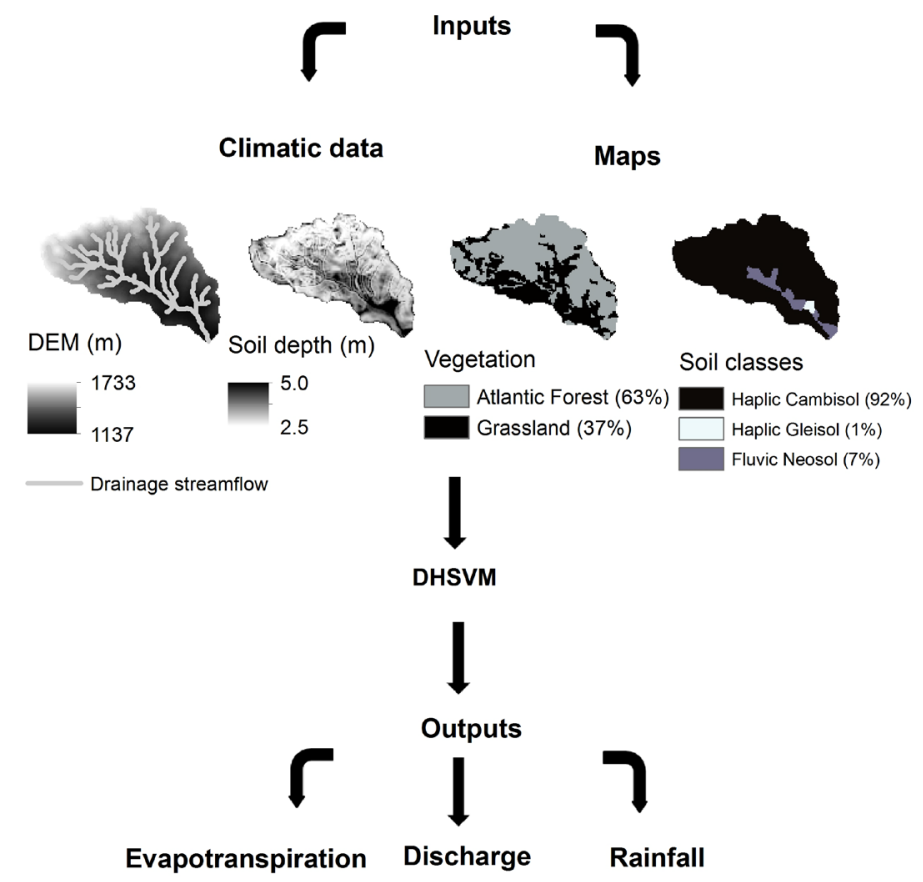

Figure 2. Inputs and outputs of the DHSVM.

year to September of the following year. The accuracy of DHSVM in simulating monthly discharge was evaluated using the coefficient of efficiency $E$ (Nash and Sutcliffe), coefficient of determination $-R^{2}$ and Percent bias- $P_{\text {bias }}$, defined as follows:

$$
\begin{gathered}
E=1.0-\frac{\sum_{i=1}^{N}\left(Q_{o i}-Q_{s i}\right)^{2}}{\sum_{i=1}^{N}\left(Q_{o i}-\overline{Q_{o}}\right)^{2}} \\
R^{2}=\left\{\frac{\sum_{i=1}^{N}\left(Q_{Q i}-\overline{Q_{O}}\right)\left(Q_{S i}-\overline{Q_{S}}\right)}{\sum_{i=1}^{N}\left[\left(Q_{Q i}-\overline{Q_{O}}\right)^{2}\right]^{0.5}\left[\left(Q_{S i}-\overline{Q_{S}}\right)^{2}\right]^{0.5}}\right\}^{2} \\
P_{\text {bias }}=\frac{\sum_{i=1}^{N}\left(Q_{o i}-Q_{s i}\right)}{\sum_{i=1}^{N}\left(Q_{o i}\right)} \times 100
\end{gathered}
$$

where $Q_{O i}$ is the observed value, $Q_{S i}$ is the simulated value, and $N$ is the number of data points corresponding to the number of time steps in a given simulation period. The $\overline{Q_{O}}$ and $\overline{Q_{S}}$ denotes the average value of a variable over the entire evaluation period.

The future projections of discharge changes in the LCC were generated with DHSVM forced by Eta-HadGEM2-ES for RCP4.5 and RCP8.5 scenarios until 2100. The study area was covered with central six points of the Eta model grid boxes and climatic data were extracted to feed the DHSVM. The DHSVM inverse-distance weighting scheme was used to transfer climate data from multiple locations. 


\subsection{The Downscaling of HadGEM2-ES under RCP4.5 and RCP8.5 Scenarios}

Eta is a regional climate model used to produce weather and climate forecasts for South America by the Brazilian National Institute for Space Research (INPE). [22] [23] used a modified version of the Eta obtained from [24]. The model simulations (5-km horizontal resolution) were produced from the Eta model which was nested into the HadGEM2-ES and these simulations were output at intervals of three hours [9]. The HadGEM2-ES global model was used in the fifth phase of the Coupled Model Intercomparison Project (CMIP5) forced by all RCPs scenarios. The HadGEM2-ES exhibits a good representation of the atmospheric conditions over South America, especially in the summer (December, January and February). The high-resolution simulations allowed describing regions with complex topography and with small scale catchments.

The Representative Concentration Pathways, RCP4.5 and RCP8.5, were taken in this study. The RCP4.5 scenario has radiative forcing of $4.5 \mathrm{~W} \mathrm{~m}^{-2}$; the radiative forcing increases almost linearly up to 2060 when the increase rate slows until the end of the 2100, where it stabilizes. The RCP8.5 scenario, with radiative forcing of $8.5 \mathrm{~W} \mathrm{~m}^{-2}$, is characterized by a continuous increasing greenhouse gas emission beyond 2100 [25].

\section{Results and Discussion}

\subsection{DHSVM Performance}

To evaluate performance of the DHSVM, the sensitivity of the simulations to the soil parameterization was studied. Vegetation parameters were not changed in the calibration. The presented vegetation and soil (Figure 2) and respective parameters were extrapolated for future simulations (scenarios) to evaluate the impacts on the hydrological regime only as a result to the climatic changes.

The model was calibrated and validated to the monthly mean observed discharge at the outlet of LCC by adjusting the lateral and vertical hydraulic conductivity and the exponent for decreasing the lateral hydraulic conductivity with the depth through soil parameters. After calibration, all parameters were updated in DHSVM, and the model simulated the validation period. A more detailed description of DHSVM calibration can be found in [3].

Monthly average hydrograph for the calibration and validation periods are presented in Figure 3. The comparison of the simulated and observed hydrographs reveals: 1) that the observed and predicted monthly discharge hydrographs showed reasonable agreement for both calibration and validation periods; 2) the simulation closely estimates the peak flows and the recession period. According to [26], DHSVM performance is considered "good" for the calibration and validation periods $\left(\mathrm{R}_{\text {calibration }}^{2}=0.70 ; \mathrm{E}_{\text {calibration }}=0.63 ; \mathrm{P}_{\text {bias calibration }}=3.13\right.$ and $\left.R_{\text {validation }}^{2}=0.85 ; E_{\text {validation }}=0.77 ; P_{\text {bias validation }}=-13.21\right)$. Thus, these results suggest that DHSVM may be useful for simulations of the hydrological impacts under RCP4.5 and RCP8.5 scenarios, i.e., with focus on the long-term trend. 

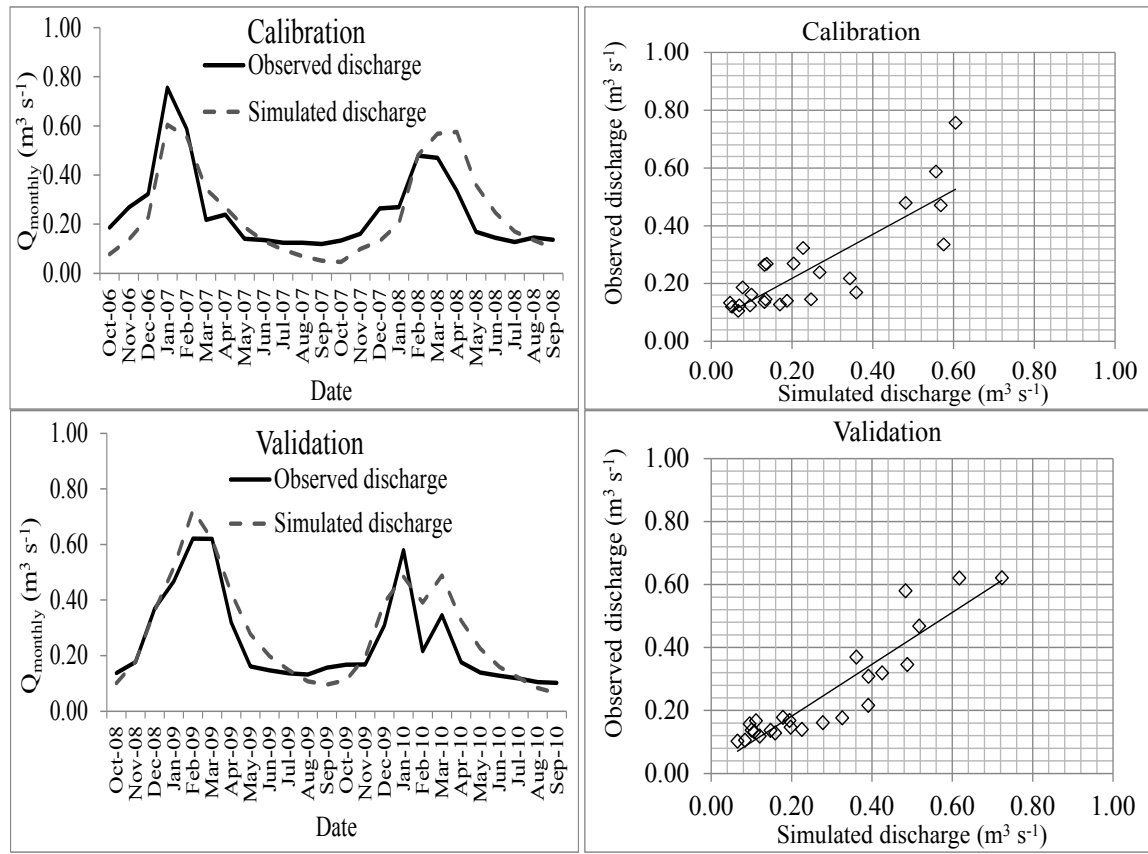

Figure 3. Observed and simulated discharge $\left(\mathrm{m}^{3} \mathrm{~s}^{-1}\right)$ during model calibration and validation periods.

\subsection{Changes Projected by DHSVM Driven by the $5 \mathrm{Km}$ Eta Simulations}

The baseline period simulations and observed data from regions around LCC are in agreement, which gives confidence in the up of future RCPs scenarios to force DHSVM and to simulate the impacts in water resources in the region [12]. In addition, an important aspect of these simulations is that high-resolution $5-\mathrm{km}$ Eta model can capture topographic features and extreme values better than the resolution $20-\mathrm{km}$. In general, these high-resolution runs resulted in a bias reduction [27]. Temperature and precipitation was analyzed in the LCC, for the HadGEM2-ES in the RCP4.5 and RCP8.5 scenarios, throughout the 21st century, in comparison with the baseline period. The results showed that both scenarios presented an increase in the seasonal average air temperature (summer, autumn, winter and spring). The impacts simulated under the RCP8.5 scenario are larger, with an increase in the temperature over $5^{\circ} \mathrm{C}$ by the end of the 21 st century, in all seasons. In addition, summer showed greater impact, indicating an increase in temperature over exceeding $6^{\circ} \mathrm{C}$. Considering the RCP4.5 scenario, there were increases in temperature between $2.0^{\circ} \mathrm{C}$ and $3.0^{\circ} \mathrm{C}$, for the four seasons. Regarding the projected precipitation, there is no clear trend in the autumn, winter and spring for the RCP4.5 and RCP8.5 scenarios, but a sign of reduction in the summer in both scenarios toward the end of the century.

These results are consistent with the studies carried out by [23] and [9]. In a study of climate change in South America using Eta/HadGEM2-ES projections, [23] showed increase in temperature in summer, from about $3.5^{\circ} \mathrm{C}$ and $5.0^{\circ} \mathrm{C}$ under RCP4.5 scenario, and over $7.0^{\circ} \mathrm{C}$ under RCP8.5 scenario, in the Center 
South region of Brazil. In addition, for the winter season, in the same region, these authors obtained temperature increases from about $2.5^{\circ} \mathrm{C}$ to $4.0^{\circ} \mathrm{C}$ under RCP4.5 and over $7.0^{\circ} \mathrm{C}$ under RCP8.5. In the study of impacts on tropical forest of Central America, the projections of Eta/HadGEM2-ES indicate an increase in the annual average temperature at the end of the 21 st century (2071 to 2099), when compared with the baseline period between 1961 and 1990 [9]. These projections show warming of about $3.0^{\circ} \mathrm{C}$ and $3.5^{\circ} \mathrm{C}$ under $\mathrm{RCP} 4.5$ and $6.0^{\circ} \mathrm{C}$ and $7.0^{\circ} \mathrm{C}$ under RCP8.5. [23] also found more uncertainties in the precipitation projections than temperature projections in South America.

The average changes in discharge projected by DHSVM simulations, for the three time slices, and under RCP4.5 and RCP8.5 scenarios, are shown in Table 2, split in summer (DJF), autumn (MAM), winter (JJA) and spring (SON). The discharge projections show a clear sensitivity of seasonal average discharges to temperature and precipitation changes. The major reduction of average discharge (\%) was found in DJF, considering all time slices and RCPs, in comparison with the other seasons. This discharge reduction in the summer follows the tendency of temperature increase and precipitation reduction throughout the 21 st century. The sensitivity of the runoff to climate changes under both RCPs scenarios was more highlighted for the time slices of 2011-2040 and 2071-2099.

This research also suggests underestimation bias of the simulated discharges, as can be seen in the Table 2 (1961-1990) when compared to observed discharges (2006-2010) in the Figure 3. These differences are likely because of an underestimation of precipitation from the Eta model. Despite the uncertainties of the simulated projections i.e. climate data without bias-corrected and simulations using only a Global Model, DHSVM reasonably simulated discharge in the baseline period. Climate change related risk involves uncertainty about the severity of the impacts in the Mantiqueira Range region. It should also be highlighted that, since 2013, this region has suffer with annual observed rainfall values below average. Thus, effects of drought have been critical, indicating the importance of these results, despite all the limitations.

\subsection{Water Budget Responses}

Table 3 shows the water budget at LCC simulated by DHSVM for the baseline period and under RCP4.5 (a) and RCP8.5 scenarios (b). For the baseline period (1961-1990), the water budget indicated a water deficit in April, May, June, and July months. Observed data (Rainfall-Evapotranspiration) from a meteorological station in the LCC, during the years 2006 to 2010, although it is a shorter period, also showed negative water budget in May, June, July and August months. In general, the water deficit of the simulated data (baseline period) coincides with these observed data along with the dry season in the studied region [12] [28].

Regarding RCP4.5 scenario, the largest water deficit occurred in the first time slice of the 21st century (2011-2040), when the dry period extended from March 
Table 2. Change in the seasonal average discharge $\left(\mathrm{m}^{3} \mathrm{~s}^{-1}\right)(\%)$, projected by DHSVM, under RCP4.5 and RCP8.5 (time slice), in comparison with the baseline period.

\begin{tabular}{cccccccc}
\hline Season & $\begin{array}{c}\text { Baseline } \\
(1961-1990)\end{array}$ & $\begin{array}{c}2011-2040 \\
(\text { RCP4.5) }\end{array}$ & $\begin{array}{c}2041-2070 \\
(\text { RCP4.5) }\end{array}$ & $\begin{array}{c}2071-2099 \\
(\text { RCP4.5) }\end{array}$ & $\begin{array}{c}2011-2040 \\
(\text { RCP8.5) }\end{array}$ & $\begin{array}{c}2041-2070 \\
\text { (RCP8.5) }\end{array}$ & $\begin{array}{c}2071-2099 \\
\text { (RCP8.5) }\end{array}$ \\
\hline Summer (DJF) & 0.229 & $0.045(-80.35 \%)$ & $0.065(-71.62 \%)$ & $0.078(-65.94 \%)$ & $0.094(-58.95 \%)$ & $0.08(-65.07 \%)$ & $0.059(-74.24 \%)$ \\
Autumn (MAM) & 0.231 & $0.058(-74.89 \%)$ & $0.071(-69.26 \%)$ & $0.074(-67.97 \%)$ & $0.083(-64.07 \%)$ & $0.083(-64.07 \%)$ & $0.065(-71.86 \%)$ \\
Winter (JJA) & 0.104 & $0.029(-72.12 \%)$ & $0.073(-29.81 \%)$ & $0.038(-63.46 \%)$ & $0.042(-59.62 \%)$ & $0.044(-57.69 \%)$ & $0.039(-62.50 \%)$ \\
Spring (SON) & 0.090 & $0.021(-76.67 \%)$ & $0.042(-53.33 \%)$ & $0.05(-44.44 \%)$ & $0.043(-52.22 \%)$ & $0.06(-33.33 \%)$ & $0.041(-54.44 \%)$ \\
\hline
\end{tabular}

Table 3. Monthly average rainfall (R), evapotranspiration (ET) and water budget (R-ET) ( $\mathrm{mm} \mathrm{month}^{-1}$ ), simulated by DHSVM at LCC, for baseline (1961-1990), and RCP4.5 (a) and RCP8.5 (b) scenarios, in three time slices (2011-2040, 2041-2070 and 2071-2099).

(a)

\begin{tabular}{cccccccccccccc}
\hline \multirow{2}{*}{ Month } & \multicolumn{3}{c}{ Baseline (1961-1990) } & \multicolumn{2}{c}{ 2011-2040 (RCP4.5) } & \multicolumn{2}{c}{ 2041-2070 (RCP4.5) } & \multicolumn{2}{c}{ 2071-2099 (RCP4.5) } \\
\cline { 2 - 12 } & R & ET & R-ET & R & ET & R-ET & R & ET & R-ET & R & ET & R-ET \\
\hline Oct & 130.0 & 106.8 & 23.2 & 96.5 & 87.3 & 9.3 & 105.8 & 91.1 & 14.7 & 119.9 & 94.9 & 25.0 \\
Nov & 158.0 & 103.6 & 54.4 & 108.6 & 86.8 & 21.7 & 114.5 & 92.6 & 21.9 & 121.8 & 93.3 & 28.6 \\
Dec & 200.2 & 126.1 & 74.1 & 123.3 & 115.0 & 8.2 & 119.5 & 112.9 & 6.5 & 140.3 & 126.9 & 13.4 \\
Jan & 198.4 & 129.2 & 69.1 & 142.7 & 121.5 & 21.2 & 138.7 & 107.2 & 31.6 & 145.5 & 121.6 & 23.9 \\
Feb & 159.9 & 113.6 & 46.3 & 140.0 & 105.1 & 34.9 & 131.8 & 110.0 & 21.9 & 131.6 & 110.2 & 21.4 \\
Mar & 137.2 & 107.6 & 29.5 & 99.0 & 101.5 & -2.5 & 108.8 & 102.5 & 6.3 & 114.5 & 110.9 & 3.6 \\
Apr & 70.3 & 88.7 & -18.4 & 62.6 & 78.8 & -16.1 & 58.6 & 75.8 & -17.2 & 53.8 & 86.5 & -32.7 \\
May & 38.1 & 79.2 & -41.1 & 32.1 & 54.9 & -22.8 & 27.1 & 58.7 & -31.6 & 38.1 & 59.1 & -21.0 \\
Jun & 30.2 & 42.3 & -12.1 & 21.2 & 30.9 & -9.7 & 20.9 & 28.1 & -7.2 & 29.2 & 37.9 & -8.6 \\
Jul & 52.7 & 55.8 & -3.1 & 32.3 & 36.7 & -4.4 & 46.2 & 39.8 & 6.5 & 52.4 & 47.0 & 5.4 \\
Aug & 76.4 & 61.8 & 14.6 & 42.9 & 45.6 & -2.7 & 65.8 & 53.9 & 11.9 & 52.1 & 50.4 & 1.7 \\
Sep & 104.9 & 85.9 & 19.0 & 65.8 & 60.5 & 5.3 & 77.4 & 72.7 & 4.7 & 96.9 & 73.8 & 23.1 \\
\hline
\end{tabular}

(b)

\begin{tabular}{|c|c|c|c|c|c|c|c|c|c|}
\hline \multirow{2}{*}{ Month } & \multicolumn{3}{|c|}{$2011-2040$ (RCP8.5) } & \multicolumn{3}{|c|}{$2041-2070$ (RCP8.5) } & \multicolumn{3}{|c|}{ 2071-2099 (RCP8.5) } \\
\hline & $\mathbf{R}$ & ET & R-ET & $\mathbf{R}$ & ET & R-ET & $\mathbf{R}$ & ET & R-ET \\
\hline Oct & 102.8 & 80.1 & 22.7 & 97.5 & 89.8 & 7.7 & 101.2 & 76.0 & 25.2 \\
\hline Nov & 100.1 & 79.8 & 20.3 & 79.6 & 74.8 & 4.9 & 68.9 & 74.3 & -5.4 \\
\hline Dec & 101.6 & 97.9 & 3.7 & 130.1 & 98.0 & 32.0 & 89.6 & 77.2 & 12.4 \\
\hline Jan & 149.3 & 104.5 & 44.8 & 155.6 & 111.0 & 44.6 & 115.6 & 87.5 & 28.2 \\
\hline Feb & 123.7 & 103.2 & 20.5 & 154.8 & 119.6 & 35.2 & 113.9 & 95.6 & 18.3 \\
\hline Mar & 111.0 & 101.7 & 9.3 & 115.8 & 116.1 & -0.3 & 92.9 & 88.4 & 4.5 \\
\hline Apr & 46.7 & 72.5 & -25.8 & 64.8 & 84.5 & -19.7 & 50.0 & 66.9 & -16.9 \\
\hline May & 26.9 & 50.3 & -23.4 & 34.3 & 66.1 & -31.9 & 18.2 & 35.5 & -17.3 \\
\hline Jun & 33.3 & 27.9 & 5.4 & 33.9 & 33.6 & 0.3 & 45.2 & 28.9 & 16.3 \\
\hline Jul & 61.1 & 45.2 & 15.9 & 56.7 & 48.8 & 7.9 & 85.8 & 60.2 & 25.6 \\
\hline Aug & 63.9 & 65.1 & -1.2 & 71.5 & 61.3 & 10.2 & 60.8 & 63.5 & -2.8 \\
\hline Sep & 81.5 & 67.7 & 13.8 & 104.2 & 74.6 & 29.6 & 67.4 & 65.5 & 1.9 \\
\hline
\end{tabular}


to August. In subsequent time slices, 2041-2070 and 2071-2099, negative vertical water budget (R-ET) occurred from April to June. These results indicate lower water availability in the LCC from 2011 to 2040 under RCP4.5 scenario. On the other hand, RCP8.5 scenario showed some more variability, ranging from positive to negative change, in the monthly vertical water budget signals throughout the 21st century. Additionally, the time slice of 2071-2099, under RCP8.5, shows less water availability, with drastic reductions in the monthly runoff (Table 3 ).

These results are in agreement with those obtained by [11], who also found increasing changes from the first to the last time slice, considering Eta/HadGEM2-ES and RCP8.5, which suggests increase in the variability of water budget signals (R-ET). In addition, this study suggests a risk of water supply shortages affecting human consumption, hydropower and agriculture, in the Grande River basin. This shown shortage should increase in the 2011-2040 and 2071-2099 time slices, under RCP4.5 and RCP8.5 scenarios, respectively.

\section{Conclusions}

The results indicated a seasonal discharge reduction during all the simulated periods and all RCPs when compared to the baseline period in the LCC using DHSVM. Under RCP4.5 and RCP8.5, runoff showed a decrease in the summer by $-80.35 \%$ and $-74.24 \%$. The most critical situation regarding water deficit is expected for the 2011-2040 and 2071-2099 time slices, for the RCP4.5 and RCP8.5 scenarios, respectively.

The assessment of the average annual water budget, in comparison with the baseline period, shows a projected water availability reduction by $83 \%, 73 \%$ and $67 \%$ and 59\%, 53\% and 65\% during three time-slices (2011-2040, 2041-2070 and 2071-2099) of the RCP4.5 and RCP8.5, respectively. The findings of this study highlight the need for a further and more extensive assessment of the potential climate change impact on the local circulation and water resources using future emission scenarios of AR5.

The climate changes may cause human health problems, alter ecosystems and cause more natural disasters; the changes may also cause a water availability reduction and freshwater security risk, as well as affect food and electricity generation prices in this region. Thus, more research in conservation practices and adaptation strategies should be conducted.

\section{Acknowledgements}

The authors would like to thank CNPq/ANA 44619, 7/2015-7 and FAPEMIG PPM X-00415-16 for partially supporting this research.

\section{References}

[1] Alvarenga, L.A., Mello, C.R., Colombo, A. and Cuartas, L.A. (2017) Hydrologic Impacts Due to the Changes in Riparian Buffer in a Headwater Watershed. Cerne, 23, 95-102. https://doi.org/10.1590/01047760201723012205

[2] Pinto, L.C., Mello, C.R. and Ávila, L.F. (2013) Water Quality Indicators in the Man- 
tiqueira Range Region, Minas Gerais State. Cerne, 19, 687-692. https://doi.org/10.1590/S0104-77602013000400020

[3] Alvarenga, L.A., Mello, C.R., Colombo, A., Cuartas, L.A. and Bowling, L.C. (2016a) Assessment of Land Cover Change on the Hydrology of a Brazilian Headwater Watershed Using the Distributed Hydrology-Soil-Vegetation Model. CATENA, 143, 7-17. https://doi.org/10.1016/j.catena.2016.04.001

[4] Pinto, L.C., Mello, C.R., Norton, L.D., Poggere, G.C., Owens, P.R. and Curi, N. (2018) A Hydropedological Approach to a Mountainous Clayey Humic Dystrudept in the Mantiqueira Range, Southeastern Brazil. Scientia Agricola, 75, 60-69. https://doi.org/10.1590/1678-992x-2016-0144

[5] Coelho, C.A., Oliveira, C.P., Ambrizzi, T., Reboita, M.S., Carpenedo, C.B., Campos, J.L.P.S., Tomaziello, A.C.N.T., Pampuch, L.A., Custódio, M.S., Dutra, L.M.M., Rocha, R.P. and Rehbein, A. (2016) The 2014 Southeast Brazil Austral Summer Drought: Regional Scale Mechanisms and Teleconnections. Climate Dynamics, 46, 11-12. https://doi.org/10.1007/s00382-015-2800-1

[6] Natividade, U.A., Garcia, S.R. and Torres, R.R. (2017) Tendência dos índices de extremos climáticos observados e projetados no Estado de Minas Gerais. Revista Brasileira de Meteorologia, 32, 600-614. https://doi.org/10.1590/0102-7786324008

[7] Nobre, C.A., Marengo, J.A., Seluchi, M.E., Cuartas, L.A. and Alves, L.M. (2016) Some Characteristics and Impacts of the Drought and Water Crisis in Southeastern Brazil during 2014 and 2015. Journal of Water Resource and Protection, 8, 252-262. https://doi.org/10.4236/jwarp.2016.82022

[8] Cavalcanti, I.F.A., Nunes, L.H., Marengo, J.A., Gomes, J.L., Silveira, V.P. and Castellano, M.S. (2017) Projections of Precipitation Changes in Two Vulnerable Regions of São Paulo State, Brazil. American Journal of Climate Change, 6, 268-293. https://doi.org/10.4236/ajcc.2017.62014

[9] Lyra, A., Imbach, P., Rodriguez, D., Chou, S.C., Georgiou, S. and Rarofolo, L. (2017) Projections of Climate Change Impacts on Central America Tropical Rainforest. Climatic Change, 141, 93-105. https://doi.org/10.1007/s10584-016-1790-2

[10] Salviano, M.F., Groppo, J.D. and Pellegrino, G.Q. (2016) Análise de tendências em dados de precipitação e temperatura no Brasil. Revista Brasileira de Meteorologia, 31, 64-73. https://doi.org/10.1590/0102-778620150003

[11] Neto, A.R., Paz, A.R., Marengo, J.A. and Chou, S.C. (2016) Hydrological Processes and Climate Change in Hydrographic Regions of Brazil. Journal of Water Resource and Protection, 8, 1103-1127. https://doi.org/10.4236/jwarp.2016.812087

[12] Alvarenga, L.A., Mello, C.R., Colombo, A., Cuartas, L.A. and Chou, S.C. (2016b) Hydrological Responses to Climate Changes in a Headwater Watershed. Ciência e Agrotecnologia, 40, 647-657. https://doi.org/10.1590/1413-70542016406027716

[13] Cuo, L., Lettenmaier, D.P., Alberti, M. and Richey, J.E. (2009) Effects of a Century of Land Cover and Climate Change on the Hydrology of the Puget Sound Basin. Hydrological Processes, 23, 907-933. https://doi.org/10.1002/hyp.7228

[14] Dickerson-Lange, S. and Mitchell, R. (2014) Modeling the Effects of Climate Change Projections on Streamflow in the Nooksack River Basin, Northwest Washington. Hydrological Processes, 28, 5236-5250. https://doi.org/10.1002/hyp.10012

[15] Safeeq, M. and Fares, A. (2012) Hydrologic Response of a Hawaiian Watershed to Future Climate Change Scenarios. Hydrological Processes, 26, 2745-2764. https://doi.org/10.1002/hyp.8328

[16] Oliveira, V.A., Mello, C.R., Viola, M.R. and Srinivasan, R. (2017) Assessment of Climate Change Impacts on Streamflow and Hydropower Potential in the Headwater Region of the Grande River Basin, Southeastern Brazil. International Journal of 
Climatology, 37, 1-19. https://doi.org/10.1002/joc.5138

[17] Viola, M.R., Mello, C.R., Chou, S.C., Yanagi, S.N. and Gomes, J.L. (2015) Assessing Climate Change Impacts on Upper Grande River Basin Hydrology, Southeast Brazil. International Journal of Climatology, 35, 1054-1068. https://doi.org/10.1002/joc.4038

[18] Wigmosta, M.S., Vail, L.W. and Lettenmaier, D.P. (1994) A Distributed Hydrology-Vegetation Model for Complex Terrain. Water Resources Research, 30, 1665-1679. https://doi.org/10.1029/94WR00436

[19] Swinbank, W.C. (1963) Long-Wave Radiation from Clear Skies. Quarterly Journal of the Royal Meteorological Society, 89, 339-348.

https://doi.org/10.1002/qj.49708938105

[20] Oliveira, A.S., Silva, A.M., Mello, C.R. and Alves, G.J. (2014) Stream Flow Regime of Springs in the Mantiqueira Mountain Range Region, Minas Gerais State. Cerne, 20, 343-349. https://doi.org/10.1590/01047760201420031268

[21] Menezes, M.D., Junqueira Júnior, J.A., Mello, C.R., Silva, A.M., Curi, N. and Marques, J.J. (2009) Dinâmica hidrológica de duas nascentes, associada ao uso do solo, características pedológicas e atributos físico-hídricos na sub-bacia hidrográfica do Ribeirão Lavrinha-Serra da Mantiqueira (MG). Scientia Forestalis, 37, 175-184.

[22] Chou, S.C., Lyra, A., Mourão, C., Dereczynski, C., Pilotto, I., Gomes, J., Bustamante, J., Tavares, P., Silva, A., Rodrigues, D., Campos, D., Chagas, D., Sueiro, G., Siqueira, G., Nobre, P. and Marengo, J. (2014) Evaluation of the Eta Simulations Nested in Three Global Climate Models. American Journal of Climate Change, 3, 438-454. https://doi.org/10.4236/ajcc.2014.35039

[23] Chou, S.C., Lyra, A., Mourão, C., Dereczynski, C., Pilotto, I., Gomes, J., Bustamante, J., Tavares, P., Silva, A., Rodrigues, D., Campos, D., Chagas, D., Sueiro, G., Siqueira, G. and Marengo, J. (2014) Assessment of Climate Change over South America under RCP 4.5 and 8.5 Downscaling Scenarios. American Journal of Climate Change, 3, 512-527. https://doi.org/10.4236/ajcc.2014.35043

[24] Mesinger, F., Chou, S.C., Gomes, J.L., Jovic, D., Bastos, P., Bustamante, J.F., Lazic, L., Lyra, A.A., Morelli, S., Ristic, I. and Veljovic, K. (2012) An Upgraded Version of the Eta Model. Meteorology and Atmospheric Physics, 116, 63-79. https://doi.org/10.1007/s00703-012-0182-Z

[25] IPCC (2013) Climate Change 2013: The Physical Science Basis. Contribution of Working Group I to the Fifth Assessment Report of the Intergovernmental Panel on Climate Change. Cambridge University Press, Cambridge and New York, 1535. https://doi.org/10.1017/CBO9781107415324

[26] Moriasi, D.N., Arnold, J.G., van liew, M.W., Bingner, R.L., Harmel, R.D. and Veith, T.L. (2007) Model Evaluation Guidelines for Systematic Quantification of Accuracy in Watershed Simulations. Transactions of the ASABE, 50, 885-900.

https://doi.org/10.13031/2013.23153

[27] Lyra, A., Tavares, P., Chou, S.C., Sueiro, G., Dereczynski, C., Sondermann, M., Silva, A., Marengo, J. and Giarolla, A. (2017) Climate Change Projections over Three Metropolitan Regions in Southeast Brazil Using the Non-Hydrostatic Eta Regionalclimate Model at 5-km Resolution. Theoretical and Applied Climatology, 132, 663-682. https://doi.org/10.1007/s00704-017-2067-z

[28] Mello, C.R., Fernandes, L., Norton, L.D., Silva, A.M., Mello, J.M. and Beskow, S. (2011) Spatial Distribution of Top Soil Water Content in an Experimental Catchment of Southeast Brazil. Scientia Agricola, 68, 285-294. https://doi.org/10.1590/S0103-90162011000300003 